\title{
MEMBANGUN MENTAL MENGHADAPI UJIAN NASIONAL
}

\author{
${ }^{1}$ Destian Andhani, ${ }^{2}$ I Nyoman Marayasa, ${ }^{3}$ Budi Haryono, ${ }^{4}$ Ida Nurlina, ${ }^{5}$ Umar Hanis \\ 12,3,4,5 Prodi Akuntansi S1, Fakultas Ekonomi, Universitas Pamulang \\ dosen02464@unpam.ac.id, dosen00569@unpam.ac.id,dosen00980@unpam.ac.id, \\ dosen01477@unpam.ac.id, umarhanis46@gmail.com \\ Korespondensi penulis : dosen02464@unpam.ac.id
}

\begin{abstract}
Abstrak
Tujuan dari kegiatan pengabdian kepada masyarakat diharapkan menjadi kegiatan berkesinambungan untuk membantu masyarakat dalam menangani permasalahan yang mereka hadapi. Terlebih jika output dari kegiatan tersebut jelas, manfaat dari penelitian tersebut dapat berefek langsung bagi masyarakat. Metode yang digunakan pada pengabdian kepada masyarakat ini berupa membangun mental siswa/i dalam menghadapi ujian nasional dan mendapatkan hasil yang terbaik. Dalam hal ini ditunjukan dengan melakukan peningkatan pembelajaran siswa, mulai dari persiapan fisik hingga kepada mental siswa melalui pengabdian kepada masyarakat ini. Hasil pengabdian masyarakat yang diperoleh adalah bertambahnya keilmuan bagi para para siswa/i yang dilakukan pada SMP Negeri 83 Jakarta yang berlokasi di Jl. Empang Bahagia Raya Jelambar, Kec. Grogol Petamburan, Kota Jakarta Barat Prov. D.K.I. Jakarta, dengan siswa/i berjumlah 571 perserta, agar mereka memiliki pandangan yang baik bagaimana membangun mental dalam menghadapi ujian nasional maka, para siswa/i bisa menerapkan kiat sukses menghadapi ujian nasional ini. Serta siswa/i yang selama ini belum tahu cara belajar yang baik untuk menghadapi ujian nasional diperlukan latihan agar mendapatkan hasil yang terbaik pada ujian nasional.
\end{abstract}

Kata Kunci : Membangun Mental, UjianNasional, SMP Negeri 83Jakarta.

Abstract

The purpose of community service activities is expected to be a sustainable activity to help the community in dealing with the problems they face. Moreover, if the output of these activities is clear, the benefits of the research can have a direct effect on the community. The method used in this community service is to develop students' mentality in facing the national exam and get the best results. In this case it is demonstrated by increasing student learning, ranging from physical preparation to the mentality of students through community service. The results of community service obtained are increased knowledge for students conducted at the Jakarta State Junior High School 83, located on Jl. Empang Bahagia Raya Jelambar, Kec. Grogol Petamburan, Kota Jakarta Barat Prov. D.K.I. Jakarta, with 571 students participating, so that they have a good view of how to build mentality in the face of the national exam, students can apply the tips for success in facing this national exam. And students who have not yet known how to study well for the national exams are needed training to get the best results on the national exams.

Keywords : Mentality Building, National Examination, The Jakarta State Junior High School 83 


\section{PENDAHULUAN}

Membangun Mental Menghadapi Ujian Nasional menunjukkan bahwa banyak siswa yang sudah mempersiapkan ujian dengan matang, tetapi masih dihantui rasa takut, cemas, dan was-was. Hal ini semakin menguatkan adanya kesenjangan (gap) antara persiapan mental yang dilakukan dengan persiapan spiritual. Untuk menghadapi ujian nasional, semua pihak harus turut serta mensukseskannya. Tidak hanya para siswa, tetapi orang tua, guru dan orang orang terdekat siswa harus membantu dalam memberikan bantuan maupun doa ataupun tenaga pengajar. Ujian nasional dipilih karena banyak keunggulan.

Jadwal ujian sudah semakin dekat dan tinggal beberapa bulan lagi. Pemerintah melalui Badan Standar Nasional Pendidikan (BSNP) telah menetapkan jadwal resmi Ujian Nasional Berbasis Komputer (UNBK) untuk tahun ajaran 2019/2020. BSNP merupakan lembaga mandiri, profesional, dan independen yang ditunjuk untuk mengemban misi untuk mengembangkan, memantau pelaksanaan, dan mengevaluasi pelaksanaan standar nasional pendidikan. Jadwal UNBK ini merupakan ketetapan sesuai hasil keputusan BSNP dan rapat koordinasi BSNP dengan Direktorat terkait, Pusat Penilaian
Pendidikan Balitbang Kementerian Pendidikan dan Kebudayaan, dan Dinas Pendidikan Provinsi. Ujian nasional tahun 2020 terdapat ujian yang berbasis komputer, sehingga sekolah atau madrasah yang memiliki komputer lebih dari 20 unit dapat ditetapkan menjadi tempat pelaksana UNBK. Hal inilah yang menyebabkan UNBK 2020 tidak dilaksanakan secara serentak, agar komputer yang tersedia dapat digunakan secara bergantian (resource sharing).

Metode membangun mental dalam menghadapi Ujian Nasional maka, para siswa bisa menerapkan kiat sukses menghadapi ujian nasional ini. Serta siswa yang selama ini belum tahu cara belajar yang baik untuk menghadapi ujian nasional diperlukan latihan agar belajar menghasilkan sesuatu yang bermanfaat dan mudah diingat. Upaya agar bisa melewati UN dengan cemerlang hendaknya telah siswa siapkan sedini mungkin. Karena barang siapa bertanding tanpa perencanaan yang matang maka sama dengan merencanakan kegagalan. Berikut beberapa tips yang sekiranya bisa siswa coba untuk mengokohkan mental.

Pertama, persiapan fisik, makanmakanan yang bergizi, olah raga rutin dan tidur yang cukup adalah syarat wajib agar 
fisikmu tetap terjaga. Kedua, mengetahui teknik cara belajar yang baik. Belajar yang dianjurkan adalah yang dilakukan sedikit demi sedikit dan rutin (istiqomah). Kebiasaan belajar dengan Sistem Kebut Semalaman (SKS) menyebabkan otak menjadi cepat lelah dan sulit untuk menyimpan informasi dengan baik. Mind Mapping adalah teknik belajar yang sesuai dengan mekanisme kerja otak yakni dengan mengelompokkan informasi yang sejenis dan saling terkait sehingga memudahkan pemahaman terhadap materi pembelajaran. Jadi pelajaran itu tidak dihapal tetapi dipahami. Ketiga, pilih waktu yang tepat untuk belajar. Pagi hari menjelang subuh adalah kondisi yang baik atau fresh untuk belajar. Selain otak baru beristirahat selepas tidur dan belum ada informasi lain yang masuk selain pelajaran maka akan memudahkan daya serap terhadap materi yang dipelajari. Keempat, belajar dengan teman yang mau berbagi. Memilih teman belajar itu penting. Tidak semua teman perserta didik berkenan berbagi ilmu sehingga carilah teman yang bersedia berbagi dan menerima ilmu. Yakinlah, ilmu itu semakin diamalkan akan semakin bertambah dan berkahnya pun semakin terasa. Bisa jadi jalan lulusmu berasal dari keberkahan berbagimu.

\section{METODE}

Metode kegiatan yang digunakan adalah bekerjasama dengan Kepala Sekolah SMPN 83 Jakarta dan mencari pemasalahan yang ada di tempat tersebut sehingga dapat memberikan solusi yang tepat dalam membangun mental dalam menghadapi Ujian Nasional. Ujian nasional tahun 2020 terdapat ujian yang berbasis komputer, sehingga sekolah atau madrasah yang memiliki komputer lebih dari 20 unit dapat ditetapkan menjadi tempat pelaksana UNBK. Hal inilah yang menyebabkan UNBK 2020 tidak dilaksanakan secara serentak, agar komputer yang tersedia dapat digunakan secara bergantian (resource sharing). Setelah dianalisis maka kami memberikan pengetahuan dan pengembangan dalam membangun mental dalam menghadapi ujian nasional tahun 2020 di SMPN 83 Jakarta.

Siswa/i diharapkan fokus pada pembelajaran dan sering konsultasi dengan kakak kelas yang sudah lebih dulu menghadapi UNBK dan melakukan latihanlatihan dalam mempergunakan komputer di sekolah dan di rumah agar terbiasa menggunakan komputer agar saat ujian sudah terbiasa dan siswa/i diharapkan lebih giat belajar agar dapat lulus dengan nilai baik. 
Bagi pihak sekolah diharapkan agar selalu memberi kesempatan pada siswa/i lebih banyak menggunakan komputer agar mereka terbiasa dalam mempergunakan komputer dan memberi sosialisasi lebih banyak lagi dalam persiapan menghadapi ujian nasional berbasis komputer agar siswa bisa mendapatkan nilai yang baik. Bagi dewan guru diharapkan berperan aktif dalam memberikan latihan-latihan dalam mengerjakan soal ujian Nasional, sosialisasi pada lembaga-lembaga try out dan memberi motivasi siswa/i untuk lebih giat dalam belajar.

Metode membangun mental dalam menghadapi ujian nasional maka, para siswa/i. Kegiatan ini dimaksudkan untuk meninjau perkembangan aktualisasi masyarakat terhadap kegiatan yang telah dilakukan sebelumnya dengan harapan dapat dilaksanakan sesuai dengan teori yang telah diperoleh melalui kegiatan yang telah dilaksanakan. Evaluasi juga bertujuan untuk memahami pola pemahaman masyrakat terhadap informasi baru yang diperoleh dari pelaksana kegiatan. Hasil yang diharapkan dalam membangun mental menghadapi ujian nasional agar agar semua siswa/i bisa lulus dengan nilai dan usaha yang maksimal. ujian nasional sangat penting untuk dilaksanakan karena hasilnya bisa dijadikan sebagai pemetaan dan evaluasi sekolah. Dengan begitu, sekolah bisa memiliki potret dirinya, dan mengukur mutu sekolahnya, sehingga bisa memperbaiki diri sesuai pemetaan dari hasil ujian nasional.

\section{HASIL DAN PEMBAHASAN}

Kegiatan penyuluhan dan pembinaan di SMP Negeri 83 Jakarta beralamatkan di Jl. Empang Bahagia Raya Jelambar Kota Jakarta Barat kode pos 11460, Kelurahan / Desa Jelambar, Kecamatan Grogol Petamburan, Kota Jakarta Barat, D.K.I. Jakarta, tentang membangun mental menghadapi Ujian Nasional, penyuluan dan pembinaan ini dilakukan pada siswa/i yang berjumlah 571 peserta.

Kegiatan penyuluan dan pembinaa ini dimulai dengan pembukaan dan Ice Breaking tujuannya untuk membuat suasana lebih akrab. Setelah itu, pemateri menerangkan materi yang berkaitan dengan menumbuhkan mental dalam menghadapi ujian nasional. Respon dari siswa dan siswi sangat baik. Terlihat ketika pemateri menanyakan mental dan semangat belajar ke salah satu siswa respon siswa cepat menangkap pelajaran dari materi tersebut.

Dalam kegiatan tersebut ada beberapa perubahan yang dilihat dari siswa-siswi yang mengikuti kegiatan penyuluan dan 
pembinaan menumbuhkan mental dalam menghadapi ujian nasional karena ada beberapa juga siswa yang sangat bersemangat dan termotivasi untuk lebih giat belajar. Mereka menyadari selama ini mereka sudah menyia-nyiakan waktu dalam belajar, dan mereka juga bertekad untuk lebih semangat dalam belajar agar dapat membanggakan kedua orangtuanya dengan hasil yang memuaskan serta mencapai citacita yang mereka inginkan yaitu menjadi orang sukses di masa depan.

Alhamdulillah kegiatan penyuluhan dan pembinaan menumbuhkan mental dalam menghadapi ujian nasional berjalan cukup baik, karena semua siswa aktif dan merespon dengan baik dalam kegiatan ini. Berdasarkan wawancara, tanya jawab dan pengamatan langsung selama kegiatan berlangsung, kegiatan pengabdian pada masyarakat ini memberikan hasil sebagai berikut : Meningkatnya pengetahuan dan pemahaman siswa-siswi SMP Negeri 83 Jakarta tentang tata cara belajar belajar agar menjadi siswa unggul, persiapan-persiapan dalam menghadapi ujian nasional.

Berdasarkan wawancara, tanya jawab dan pengamatan langsung selama kegiatan berlangsung, kegiatan pengabdian pada masyarakat ini memberikan hasil sebagai berikut:
1) Meningkatkan pemahaman kepada para peserta untuk membangun mental dalam menghadapi Ujian Nasional tahun 2020 di SMP Negri 83 Jakarta.

2) Meningkatkan pengetahuan kepada para peserta perisapan fisik dan teknik cara belajar yang baik dalam menghadapi Ujian Nasional tahun 2020 di SMP Negri 83 Jakarta.

3) Memberikan pengembangan dalam membangun mental dalam menghadapi Ujian Nasional tahun 2020 di SMP Negri 83 Jakarta.

Beberapa faktor yang mendukung terlaksananya kegiatan pengabdian pada masyarakat ini adalah besarnya minat dan antusiasme peserta selama kegiatan, sehingga kegiatan berlangsung dengan lancar dan efektif. Sedangkan faktor penghambatnya adalah keterbatasan waktu penyuluhan dan pembinaan.

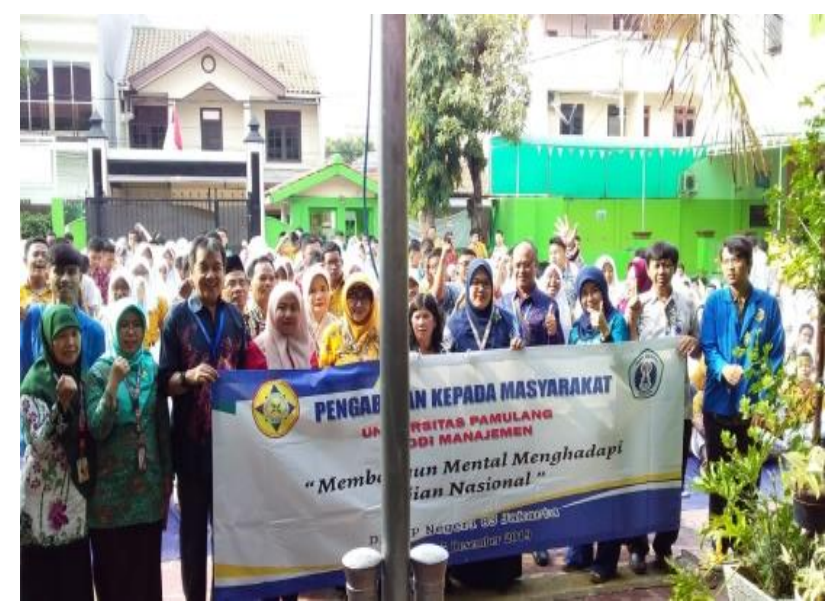

Gambar 1. Pemberian Materi oleh Tim Pengabdian Masyarakat 


\section{KESIMPULAN}

Pelaksanaan kegiatan Pengabdian

Kepada Masyarakat oleh Lembaga Penelitian dan Pengabdian Masyarakat (LPPM) Universitas Pamulang yang dilakukan oleh dosen-dosen program studi Manajemen telah berjalan dengan lancar dan mendapat sambutan hangat dari tempat pelaksanaan kegiatan ini yaitu Kepala SMP Negri 83 Jakarta. Harapan kami dengan pengabdian ini dapat menambah ilmu yang bermanfaat dalam memberikan pemahaman kepada siswa agar dapat mempersiapkan mental dalam menghadapi ujian nasional.

Harapan kami dengan pengabdian ini dapat memberikan peningkatan semangat serta persiapan mental dari siswa siswi dalam menghadapi ujian nasional. Materi yang kami berikan yaitu penyuluhan dan pembinaan sehingga dapat membantu dalam persiapan mental siswa dan siswi dalam menghadapi ujian nasional.

\section{REFERENSI}

Gultom, Syawal (2012) "Ujian Nasional Sebagai Wahana Evaluasi Pengembangan Pendidikan Karakter Bangsa". Dalam Khairil Anwar (Ed.) 2012. Ujian Nasional: Sarana Untuk Membangun Karakter Bangsa. Jakarta: Kementerian Pendidikan dan Kebudayaan.

Evaluasi
Pengembangan Pendidikan Karakter Bangsa. Jurnal Pendidikan, 3(1). Hal. 5.

Hakim, Thursan (2002) Mengatasi Rasa Tidak Percaya Diri. Jakarta:Puspa Swara.

Kemdikbud. (2003). Undang-undang RI No.20 tahun 2003 tentang sistem pendidikan nasional.

Setiadi, Hari (2012) Dampak Ujian Nasional Pada Karakter Bangsa. Dalam Khairil Anwar (Ed.) 2012. Ujian Nasional: Sarana Untuk Membangun Karakter Bangsa. Jakarta: Kementerian Pendidikan dan Kebudayaan. Tilaar, H.A.R. 2006. Standarisasi Pendidikan Nasional. Jakarta: PT. Rineka Cipta.

Vivi Iswanti Nursyirwan, Sasmita Sari Ardaninggar, Liana Dwi Septiningrum, Dewi Rani Gustiasari, Julian Muhammad Hasan. (2019). Peningkatan Volume Penjualan Melalui Pelatihan Materi Dan Praktik Digital Marketing Bagi Para Pelaku Usaha Kecil Mikro-Pertanian Kota Depok (UKM-P). ABDIMISI Vol. 1 No. 1 Desember 2019. Hal.24

https://edukasi.kompas.com/read/2019/10/ 01/08522931/jadwal-ujian-nasionalsmp-mts-2020-sudah-ditetapkan (diakses pada 08 Januari 2020)

https://jogja.tribunnews.com/2020/02/28/ja dwal-ujian-nasional-berbasiskomputer-unbk-sma-smk-hinggasmpmts-2020 (diakses pada 16 September 2020)

https://edukasi.kompas.com/read/2019/10/01 /08522931/jadwal-ujian-nasionalsmp-mts-2020-sudah-ditetapkan-cekdi-sini?page $=$ all 